This item was submitted to Loughborough's Research Repository by the author.

Items in Figshare are protected by copyright, with all rights reserved, unless otherwise indicated.

\title{
The opening of the state security archives of central and eastern Europe
}

\section{PLEASE CITE THE PUBLISHED VERSION}

https://doi.org/10.1080/08850607.2014.842794

\section{PUBLISHER}

Taylor and Francis

\section{VERSION}

AM (Accepted Manuscript)

\section{PUBLISHER STATEMENT}

This work is made available according to the conditions of the Creative Commons Attribution-NonCommercialNoDerivatives 4.0 International (CC BY-NC-ND 4.0) licence. Full details of this licence are available at: https://creativecommons.org/licenses/by-nc-nd/4.0/

\section{LICENCE}

CC BY-NC-ND 4.0

\section{REPOSITORY RECORD}

Maddrell, Paul. 2019. "The Opening of the State Security Archives of Central and Eastern Europe". figshare. https://hdl.handle.net/2134/34147. 
PAUL MADDRELL, LOUGHBOROUGH UNIVERSITY, UNITED KINGDOM

E-mail: maddrell.paul@gmail.com

Tel.: 00-44-1509-222972

ANNUAL CONVENTION OF THE INTERNATIONAL STUDIES

ASSOCIATION, SAN FRANCISCO, CALIFORNIA, 3-6 APRIL 2013

THE OPENING OF THE STATE SECURITY ARCHIVES OF CENTRAL AND EASTERN EUROPE

THIS PAPER REPRESENTS WORK IN PROGRESS AND SHOULD NOT BE CITED WITHOUT THE PERMISSION OF THE AUTHOR 


\section{The Opening of the State Security Archives of Central and Eastern Europe}

\section{Introduction}

In laws passed since $1991^{1}$ the state security archives of the former Communist states of Central and Eastern Europe have been opened. This paper examines why they have been opened and what the results have been (and are likely in future to be). It surveys the legislation in place throughout the former Soviet Bloc but focuses in particular on the opening of the archives in Germany and Romania. The reason for this is that the process is far advanced in Germany and much less advanced in Romania. The contrast between the two displays the issues involved very well. The paper argues that the opening of the archives has been an important tool of de-communization. It has been fullest in Germany because of the strength and self-confidence of the German legal system and because of the weakness of the Communists' political position. It has been partial in Romania because the legal system lacks authority, independence and self-confidence and the Communists have remained strong.

There are important differences between the various countries, but, generally speaking, the institutions which hold the former state security records have four tasks:

(a) to enable the connections of public officials with the former Communist security and intelligence services to be investigated so that those who did collaborate with those services can be removed from public office ("lustration", as it is called);

(b) to make available to targets of surveillance and repression the records held on them; 
(c) to make records available for the prosecution of those who committed crimes during the period of Communist rule; and

(d) to enable historians and journalists to write the history of Communist surveillance and repression.

Broadly speaking, these four tasks serve the purposes of building stable democratic institutions which enjoy public trust and of giving victims of the Communist security services a measure of retrospective justice. ${ }^{2}$

\section{Vetting and lustration}

All societies where totalitarian dictatorships have collapsed or been overthrown have faced the problem of finding a way of reconciling their many victims with their many collaborators. Since the Communist regimes of Central and Eastern Europe were overthrown in a wave of revolution, the demand that the security services' collaborators be exposed was strong. Many - though not all - of the triumphant democrats believed that their countries' political and economic health depended on either removing ex-Communists from political and economic life or at least on knowing who they were. They wanted to encourage their peoples to have trust in the new democratic institutions, which needed, therefore, to function transparently. They also wanted them to have trust in one another, which their societies had lacked in Communist times. Building a social and political order which had clearly overcome the harm the Communists had done would also assist reconciliation with them (those who favoured opening the state security archives had to counter the claim that keeping them closed would assist reconciliation between the two wings of society). 
This view of exposing police informers was expressed by the Romanian historian Vladimir Tismaneanu, when he commented, "Reconciliation cannot be attained through the reproduction of lies". ${ }^{3}$ The Polish Solidarity leader Adam Michnik expressed the same view with his aphorism, "Amnesty yes, amnesia no". For some years after 1989-91 there was also a fear that the new democratic systems might be overthrown by the Communists; the exposure of informers and security officials was seen as essential to secure democracy.

Owing to the security services' central role in the Communist regimes (and in particular in their infringements of human rights), any vetting process would inevitably rely very heavily on state security records. Of course, the Communists and their many collaborators were always going to resist this so as to prevent their participation in discredited regimes from being exposed. Many of those involved in the civil rights movements that overthrew them were also hostile to the archives being opened because they did not want their collaboration with the security services to become public knowledge either. ${ }^{4}$

Nevertheless, in most of the countries of the former Soviet Bloc there have been moves to vet those in public office and remove them for a time from their positions. These lustration policies are the direct successors of the denazification policy pursued by the victorious Allies in their occupation zones in Germany after the Second World War.

In Germany, the ex-Communists' ability to resist this was particularly small since the German Democratic Republic (GDR) ceased to exist and the united German state had 
a strong judicial system and a very anti-Communist political culture. The strength of the judicial system came from its self-confidence, the explicit commitment in the Federal Republic's Basic Law to the rule of law and respect for legal rights, a long German legal tradition, and the deference of German politicians to judicial authority. None of these exist in Romania. Moreover, in sharp contrast to Romania, the East German security service, the Stasi, ceased to exist after the revolution which overthrew the Communist regime and the East German civil rights movement seized many of its record depositories. ${ }^{5}$ The Unification Treaty between the two German states, concluded in August 1990, provided that any who had collaborated with or worked for the Stasi or engaged in violations of human rights should be removed from public office if their actions were sufficiently serious to make them "appear unsuitable" for it. ${ }^{6}$

The German Parliament, the Bundestag, advanced the lustration process in December 1991, when it passed its Law on the Stasi Records (Stasi-Unterlagen-Gesetz, StUG). The law is severe, providing for wide-ranging vetting of those in the public service. The public service is construed broadly, extending from politicians, judges and army officers to teachers and civil servants. There has also been limited vetting of those in leading positions in the private sector. Those subject to vetting can be denied jobs or dismissed from positions they already have. Vetting concerns only collaboration with the former GDR's State Security Ministry, not membership of the communist party, the Socialist Unity Party, even though the former served the latter. The reasoning behind this is that the party had had so many members that exclusion of all of them from employment would not have been practicable. The moral reasoning is that the law uncovers betrayal. Of course, this means that the lustration process often 
penalizes people who did very little harm to others, while no penalty at all falls on many Communist Party bosses who did great harm. ${ }^{7}$ This is even more the case when an informer acted under duress or the pressure of other mitigating circumstances. Lustration creates a social distinction between "good" and "bad" people which, firstly, is deeply resented by many of the latter and, secondly, can be hard to reconcile with the facts of a particular case. ${ }^{8}$

In 2011, by the eighth amendment to the StUG, the Bundestag extended until 2019 the responsibility for vetting of the Federal Commissioner (BStU) entrusted with the Stasi's records. ${ }^{9}$ That his/her responsibility will have lasted at least eighteen years and been repeatedly extended is a mark of how much public support the process enjoys. The BStU has no responsibility for lustration: the BStU merely informs employers who apply for information whether the Stasi held information on the person concerned and what it was. What to do about the person concerned is the responsibility of the employer. Many former Stasi informers have not, in fact, been dismissed from their positions in the public service because their work has not been regarded as harmful enough. Estimates of the number of dismissals on this ground vary. One is that by 1996 between 60,000 and 100,000 people had been dismissed from their jobs for collaboration of one kind or another with the Stasi. Another puts the figure at just over $10,000 .^{10}$

The Czech law was also passed quickly (in 1991). It was also severe, providing that not only security officials and secret police informers but also Communist Party officials were to be excluded for five years from both public office and prominent 
positions in the private sector. This prohibition was not dependent on any participation by these people in infringements of human rights. ${ }^{11}$

Poland settled on a moderate approach. Its first triumphant pro-democratic politicians came to power by negotiation with the Communist regime and were therefore attracted to the "Spanish model" of forgiving and forgetting. They decided not to revisit the past and Poland was slow to adopt a lustration law. It finally had to because the policy of drawing a line under the past lacked public support. Moreover, Polish politics were repeatedly racked in the 1990s by allegations that leading politicians had been secret police informers; rather than reflecting historical facts, these allegations were simply political weapons. Only authoritative rulings on their pasts could put a stop to the scandals. The country's first lustration law entered into force in 1997. It applied to the leading positions in the public service. Those affected had to submit declarations recording any collaboration on their part with the Communist-era security service. The law provided for exclusion from employment, but only if those concerned lied on their lustration certificates. To ensure that the state security records were not used for political purposes, they were transferred to an independent institution, the Institute for National Remembrance. ${ }^{12}$

The Hungarian and Romanian laws were milder still, providing only for disclosure of the past of those concerned and not for their mandatory exclusion from employment. The Hungarian law was passed in 1994, the Romanian in 1999. The Hungarian law provided that the names of former informers elected to public office would be made public if they did not quickly resign from that position. In practice, no public official found to be an informer has resigned, either before or after the finding of his 
collaboration has been made public - in other words, there has been no lustration of the public service. ${ }^{13}$ The result of each Romanian vetting procedure is published in a government journal, the Monitorul Oficial. Someone who was once an officer or informer of the Securitate is not automatically dismissed; it is, rather, hoped that he will resign. ${ }^{14}$ As will become apparent, this hope has, as in Hungary's case, not been fulfilled.

The Slovaks, who achieved their independence from Czechoslovakia in 1993, were not minded to open up the past. The Slovaks allowed their lustration law, which they inherited from Czechoslovakia, to lapse in 1996. Few prosecutions have been carried out in Slovakia either, and it has been sluggish in making its secret police files available to the public. ${ }^{15}$

The contrast between Germany and Romania is sharp. Although the Romanian revolution of December 1989 which overthrew the dictator Nicolae Ceauşescu started as an anti-Communist uprising, control of it was quickly seized by leading Communist officials who had no incentive to allow investigation of the past. Among those prominent in it were generals who changed sides after they had had demonstrators who initiated the revolution shot dead. There was no change in the country's political elite for some years after the revolution; the first genuine change of government took place in 1996 with the election of President Emil Constantinescu of the reform-minded, Christian Democrat-led Democratic Convention. The excuses used by President Ion Iliescu, who succeeded Ceauşescu as head of state, in resisting lustration before that were that it would obstruct reconciliation and that the country had more pressing problems to deal with, chief among them its economic crisis. 
This is reflected in the law on vetting of public officials and access to secret police files. No law permitting lustration was passed until 1999 (Law No. 187 of 9 December $1999^{16}$ ). This established a body to hold and examine the records of the former Romanian security service, the Securitate. This was the National Council for the Study of the Securitate Archives (Consiliul National pentru Studierea Arhivelor Securitatii, CNSAS). However, its work has consistently been frustrated by the Securitate's successor, the Romanian Intelligence Service, Romania's political parties and judges and its own incompetence and political divisions. The Romanian Information Service (Serviciul Roman de Informatii, SRI ${ }^{17}$ ) has deliberately retained or destroyed information to prevent its officers and informers from being identified. Partly this has been to protect itself and its personnel; partly it has been to protect institutions like Parliament, the government and the Presidency, in which many former security personnel ("securişti", as they are called) now work. ${ }^{18}$

Such was the reluctance of the Romanian intelligence services to hand over their records that, in practice, there was no public access to state security files until 2006. Although many files were handed over to CNSAS that year, many were retained on the ground of national security (a term which the government has not defined). The files of the leading politicians were retained on that ground, which contradicted the purpose of the law. Even after the records were transferred to it, the Council encountered considerable difficulties which have often prevented it from reaching authoritative conclusions on whether people being vetted did collaborate with the secret police. Many files are still withheld from it; others are incomplete; incriminating information has been removed by the SRI, since the revolution of 1989, 
from still more; it has been suggested that files have been tampered with to discredit as Securitate informers people who had no connection with it; the SRI has also repeatedly failed to comply with the Council's requests for information. It has withheld key information from the Council (including the card index which would have enabled informers' codenames to be matched against their real names). ${ }^{19}$

The information about the Securitate pasts of leading politicians which has come to light has often served partisan political purposes. While the files of leading Communist officials have never been found, other politicians, who have come to prominence since 1989 , have been discredited by leaks of parts of their files to the Romanian press which have shown them to have been informers. Far from being a tool for purging Romanian public life of anti-democrats, security service files have been an instrument for discrediting (and probably blackmailing) opponents of the "securişti". 20

Almost all of this is unknown in Germany. Demonstrators seized Stasi offices in late 1989 and early 1990 because they observed smoke issuing from them and assumed that files were being destroyed. Only a small part of the Stasi's archive is believed to have been lost. The archive of the foreign intelligence service, the HVA, was destroyed at the insistence of the Soviet government in the summer of 1990. The Stasi was dissolved in the first half of 1990. A "Special Commissioner" then took charge of the Stasi's records. In December 1991 he became the Federal Commissioner (BStU) responsible for them, when the Law on the Stasi Records came into force. The Law gives the BStU sole responsibility for holding the records and prescribes rights of access for third parties. 
CNSAS's first task was (until 2008) to vet candidates for political office and those who hold, or apply for, jobs in the civil or public services. It proved to be incompetent, partisan and unfair in discharging this responsibility. It was partisan because the eleven members of its governing College are nominated by the leading political parties. ${ }^{21}$ It disregarded legal safeguards given to those undergoing vetting. Consequently, there was little confidence amongst the Romanian public that its findings were correct. The Council's second task (which continues) is to make secret police files available to those they concern; it has proven to be incompetent in the discharge of this responsibility as well. ${ }^{22}$

Lustration has been a failure in Romania. The National Council has identified a very small number of people in public office as former Securitate personnel. Between 2000 and late 2011 it found that 773 ex-Securitate officers held public positions and 189 ex-informers. This represents a tiny percentage of the Securitate's staff and informer network (15,087 officers and 144,289 informers in 1989). ${ }^{23}$ Candidates for electoral office, when required by the Central Electoral Bureau to file declarations stating what involvement they had with the Securitate, have lied in those declarations. They have not been prosecuted or prevented from standing. Many have not stood down from elections when their dishonesty and past collaboration with the Securitate have been exposed. Some have gone on to win election. No politician has resigned or been dismissed from an elected position because he has been identified as an informer. ${ }^{24}$

The National Council's rulings on whether people subject to vetting were informers did not win public confidence, in part because it does not have access to the 
Securitate's entire archive and so no decision that such a person was not an informer can be entirely conclusive. Likewise, the Council is known to have cleared of collaboration with the Securitate committed Communists who very probably were informers (it had to clear them because it could not find documentary evidence of their collaboration in the archive). The Council was not able to reach any conclusion in other cases because records have been withheld from it on the ground of national security. Most fundamentally, it has been unable to reveal the extent to which former officers and informers of the Securitate are active in contemporary Romanian politics, even though that is its job. This continues to be the subject of rumour and allegation. ${ }^{25}$ Since jobs in the Romanian intelligence services are not among those subject to lustration, the Council has not even been able to establish how many officers of the post-Communist intelligence services served in the Securitate. ${ }^{26}$ Its record is so bad that in recent elections private organizations have researched the candidates' independence from the Securitate and have published the results. The lack of any effective lustration has encouraged successive incoming governments to conduct mass dismissals of public employees. However, these have been intended simply to remove political opponents. $^{27}$

The Romanian political and judicial systems have both obstructed exposure of those who worked for the Securitate. Romania has no tradition of effective or impartial justice and the judiciary has refused to prosecute people who have submitted false declarations of non-collaboration with the Securitate. ${ }^{28}$ All the leading political parties have deliberately frustrated CNSAS's work. It is widely believed that most of Romania's post-Communist leaders, regardless of their party, have had a Securitate background. ${ }^{29}$ Most bitterly opposed to it have been the successor party to the 
Communist Party, the Party of Social Democracy in Romania, and its ally, the nationalistic Greater Romania Party. Former Communist officials and ex-Securitate personnel are prominent in both of them; the memberships of both parties contain many former informers. Both parties have demanded the abolition of CNSAS.

Even parties on the pro-democratic wing of Romanian politics have tried to obstruct CNSAS's work (they deliberately postponed the adoption by Parliament of Law No. 187 until so soon before the parliamentary and Presidential elections of 2000 that the Council did not have enough time to vet the electoral candidates who were going to stand for election). To protect former Securitate informers in their ranks, they also forwarded their lists of electoral candidates to the Council for inspection late. Of those candidates it was able to vet in the time $(4,500), 10 \%$ were discovered to have informer files, but the Council went on to rule that only 38 (less than 1\%) had actually been either officers or informers of the Securitate. Those identified seemed to have been chosen to discredit the pro-democracy coalition which was then in power: twothirds of those exposed came from its ranks. Moreover, no prominent former Communists were identified; indeed, those exposed included former political prisoners. Six of the 38 were elected to parliament despite their pasts. The main party in the pro-democracy coalition, the Christian Democrats, did badly in the parliamentary elections and failed to qualify for parliamentary representation. ${ }^{30}$

The entire future of lustration in Romania is now uncertain owing to the Constitutional Court's hostility to it. In 2008 the Court held that the existing provision for lustration infringed the constitution, nullified all findings that the National Council had made up to then and opened up the possibility that it might order CNSAS to end 
its work. In response, the government transferred to the courts the responsibility for making findings as to whether people had been informers. The Romanian Parliament tried in 2012 to put lustration on a legislative basis again, but the Constitutional Court declared the proposed bill to be unconstitutional because it denied some citizens the opportunity of holding elected positions, infringed the principle on non-retroactivity and attributed collective guilt to all informers equally, which it held to be unlawful (it reasoned that guilt had to be individual). This reasoning seems politically motivated. What prospects lustration has of continuing are unclear. ${ }^{31}$

Serious disagreement between the government and the courts over lustration has not been confined to Romania. Corruption has proven to be such a persistent problem in Poland (as in Romania and elsewhere) and resentment at the former Communists' continuing influence in business and politics has been so great that in 2007 its conservative government attempted a second wave of lustration. Former Communist officials and security officers were seen as responsible for widespread, high-level corruption in business, which was put down to lustration having been too limited in the past. A new law extended the scope of vetting to the whole of the public service (not only important political positions) and to some positions in the private sector. The result was to expand the category of people required to complete a vetting certificate from 27,000 people in important jobs to all public servants born before 1 August 1972 - some hundreds of thousands of people. The vetting process would also have led to restrictions being placed on the affected person's employment even by private employers. However, the Polish Constitutional Court struck down the central provisions of the law as unconstitutional. ${ }^{32}$ 
The early trend in lustration was to keep confidential the information used. Lustration was intended to be a legal procedure subject to strict requirements of due process. However, this undermined public faith in the process and the trend now is towards making the information used publicly available. Under Poland's 1997 lustration law, information was not to be published for thirty years. The later legislation provided for the security service files to be published on the Internet.

\section{Public access to state security records}

Granting individuals who were targets of surveillance the right to see the information held on them is intended to give a measure of moral compensation. Communist rule was based on deceit and betrayal; these are, at least, overcome by showing the victim who betrayed him/her, why and with what results. This falls far short of punishment of the wrongdoer or vengeance, but it is a natural response to a Communist dictatorship. It is also a lesson in democracy for both the individual who sees his/her file and the general public. In the German case, the making available of victims' files has been supported by the educational work of the BStU and by public hearings, under the aegis of the German Parliament, into the character of the GDR dictatorship.

Germany was the first state to grant access to the records. Targets of Stasi surveillance have been reading their files since 1991. By 31 December 2010 the BStU had received approximately 2.75 million applications from German citizens to read their Stasi files. $^{33}$ 
As appears above, in 1999 Romania followed Germany's lead and passed a law granting the country's citizens (or their close relatives) the right to view their Securitate files and find out the names of those who supplied information on them. However, those exercising this right encounter significant obstacles. The first is the partial destruction of the Securitate archive in 1989 and in the decades before (see below for more on this). Another is that the applicant for access has to identify the archive where the file is held. Even if the applicant manages to do this, it would not necessarily give him or her access to the file. Some records are held at military bases to which Romanian civilians cannot gain access. Many Romanians are too poor to be able to travel to record depositories far from their place of residence. ${ }^{34}$ These practical difficulties are among the reasons why relatively few Romanians have applied to read their files: by December 2011 only 34,249 of them had submitted a request to do so. ${ }^{35}$

The Czech legislation allows for even greater openness than the German. It provides, among other things, that the Communist-era security service (StB)'s records enjoy no data protection. This gives the general public access not only to all the StB's files (files on targets as well as informers and officers) but also to all the information in them, including very sensitive personal information. In 2003 the Interior Ministry published a list of more than 100,000 StB informers on the World Wide Web. ${ }^{36}$ Hungary again represents the "forgive and forget" end of the spectrum. The 1994 lustration law also provided for public access to state security records. However, the access it granted was very limited: only targets of security operations had the right to see files; their access was only to the files on them; and the names of the informers who provided information on the target were redacted. Understandably, few 
Hungarians applied to see the files held on them (only 5,000 did so in the years 19972000). ${ }^{37}$ Subsequent amendments have widened the public's right to read the files. ${ }^{38}$

\section{Trials}

The government of the Federal Republic, in assuming responsibility for the new East German federal states in 1990, wanted to avoid imposing a retroactive victors' justice on the defeated Communists. The Federal Republic's Basic Law (its constitution), by its Article 103, paragraph 2, expressly respects the principle that legislation may not be retroactive. The Unification Treaty of 31 August 1990 between the two German states respected this principle by providing that there could only be prosecutions for crimes which were so at the times the acts in question were committed. Consequently, it laid down that prosecutions were to take place for infringements of paragraphs common to the penal codes of both the Federal Republic and the GDR. Where the two penal codes differed, the accused was to be tried under that which was more favourable to the accused. The prosecutions were difficult ones because they were evidently prompted, not by the infringement of the law of a state which no longer existed, but by a sense of moral outrage that had nothing to do with the GDR's legal code. ${ }^{39}$ Many of the Communist leaders actually died before they could be tried or were too old and frail to stand trial. The same is true of former judges and prosecutors, who therefore could not be tried for perverting justice in the service of the regime (this category of crime is called "Rechtsbeugung" in German). ${ }^{40}$

The decision to prosecute put a premium on access to reliable East German records, including ones of the Stasi. The Ministry's records were, after 1991, the principal 
source for the tens of thousands of investigations that took place into a wide range of possible crimes.

Over a ten-year period, prosecutors investigated more than 65,000 cases of injustice in East Germany during the GDR period and considered prosecution for many crimes, small as well as grave. This period ended on 3 October 2000, ten years after German unification day, when the limitation period for many of these crimes expired. The responsible prosecution authorities were the Berlin state prosecutor and the state prosecutors of the five East German federal states. Owing to the prohibition on retroactive legislation, this huge number of investigations led to a small number of prosecutions and an even smaller number of convictions.

One group of people who were investigated were the GDR's judges and state prosecutors, who had applied the GDR's criminal law expressly to persecute dissidents and maintain the Communist regime in power ("Rechtsbeugung"). Another were former officers of the Stasi, who had done terrible harm to many people (this category of crime was called "SED-Unrecht" - Communist injustice). The third main group were those responsible for the GDR's border regime, under which border guards had been required to shoot dead unarmed East Germans who were trying to flee the GDR (this category was called "Gewalttaten an der innerdeutschen Grenze" acts of violence at the inner-German border).

Particularly disturbing instances of politically-motivated persecution by judges and prosecutors were: the so-called "Waldheim trials" of 1950 in which not only Nazi war criminals but also opponents of the Communist regime were tried (and in some cases 
put to death); the legal persecutions of the victims of the purges of the 1950s, which particularly affected high Party officials and industrial managers; the trials of later, high-profile dissidents such as Robert Havemann and Rudolf Bahro; and the prosecutions of people who had tried to escape from the GDR, West Germans who had helped them and those who, from the mid-1970s on, had applied to emigrate to the West. ${ }^{41}$ In the overwhelming majority of cases (almost 90\%), no prosecution was brought, usually because of the ruling of Germany's highest court for criminal and civil cases, the Bundesgerichtshof (BGH, Federal Supreme Court), that a crime could only be considered to have been committed if the misapplication of the GDR's law had been extreme. ${ }^{42}$

The Stasi's staff were investigated for many and varied crimes. These included: the kidnapping, murder or attempted murder of people who had organized the escape of East Germans from the GDR, and of defectors from the Stasi and border guard, and of dissidents; electoral fraud; unlawful opening of post; unlawful administration of drugs to sportspeople; and crimes arising from the maltreatment of prisoners, maltreatment of demonstrators, the forced resettlement of East Germans living on the border with West Germany, and the suppression of the popular uprising of June 1953. Stasi officers were also investigated for the covert actions they had carried out to demoralize and harass East Germans (for example, by ensuring that they were dismissed from their jobs or by encouraging their friends and neighbours to turn on them). These covert actions did grave psychological harm to many.

Most Stasi officers and informers were not prosecuted because, however much harm they did to others, they could not be found to have broken the GDR's law so gravely 
that they could be prosecuted for perversion of justice (indeed, in many cases they could not be found to have broken the law of the GDR at all). As far as their participation in covert actions was concerned, for the most part prosecutions could not be brought, either because they involved no action that was criminal under any applicable law or because they were not unlawful under the GDR's law or because the Stasi officers concerned had been of such low rank that they were considered not to have been responsible for the operations. ${ }^{43}$ However, some Stasi officers were convicted of crimes (and thanks to their own Ministry's records). Among them were the GDR's long-serving State Security Minister, Erich Mielke, and its equally longserving foreign intelligence chief, Markus Wolf. Mielke was sentenced to a prison term for two murders committed in $1931 .^{44}$

The most prominent prosecutions were of those in the third group: former Communist leaders and border guards accused of the unlawful killing of would-be escapees at the border. The prosecutors concluded from their investigations that, in all, 270 people had been killed trying to flee across the inner-German border during the period of Germany's division (237 died of gunshot wounds; a further 33 tripped on mines). ${ }^{45}$

The trials took place in a political and popular atmosphere fiercely hostile to the accused, making their acquittal unlikely. Although the German courts respected the prohibition on retroactive legislation, their legal reasoning displayed considerable creativity and they were, in practice, able to overcome it. In scores of trials, border guards who had shot fleeing East Germans and the high Communist officials who had given the orders requiring them to do so raised the defence that their actions had been lawful under the law of the GDR. ${ }^{46}$ This defence failed; they were still convicted of 
having killed them unlawfully. ${ }^{47}$ The last Socialist Unity Party General Secretary Egon Krenz, the one-time GDR Defence Minister Heinz Keßler, and the army chief of staff Fritz Streletz were all sentenced to terms of imprisonment because they were considered to have been indirectly responsible for these killings. The German courts insisted that GDR law did not authorize the killing of unarmed people who posed no threat to the lives of others. The Bundesgerichtshof and Germany's highest constitutional court, the Bundesverfassungsgericht (Federal Constitutional Court), maintained that the GDR's constitution and international human rights treaties the GDR had signed required that the state protect the life of each individual; consequently, the GDR's laws could not be interpreted as authorizing its officials and armed forces to infringe human rights.

The German courts received crucial support from the European Court of Human Rights, to which Krenz, Keßler and Streletz appealed on the ground that the Federal Republic had infringed the prohibition on retroactive legislation. The European Court decided that the GDR's border regime had been designed to kill and harm wouldescapees; consequently, it infringed rights (particularly the rights to life and free movement) enshrined in both the GDR's own constitution and in international human rights treaties signed by the GDR. The appellants had, therefore, infringed both GDR law and international law in force at the time and their criminal convictions were fully justified. ${ }^{48}$ The GDR's (insincere) commitment to human rights protection was so clear that, in a later case, three former Politburo members were found guilty of manslaughter because they were held not to have discharged their duty actively to persuade the Politburo to make the state's border regime more humane. The 
Bundesgerichtshof held that this duty followed from the accused's positions in the Politburo. $^{49}$

The reality is that, in these cases, the German courts were disregarding GDR law and instead requiring compliance with international human rights law. They have not consistently adhered to this principle, however. The Bundesgerichtshof has ruled that this may only be done in cases of extreme infringement of human rights. It has further ruled that instances of GDR courts depriving East Germans of their freedom did not represent a sufficiently grave infringement of human rights for the principle to be invoked.

By October 2000, when the prosecution process was largely over, the Berlin state prosecutor (the most important of the prosecution authorities) had investigated approximately 23,000 cases. 16,503 had involved "official criminality of medium gravity" ("mittelschwere Regierungskriminalität"), which in practice meant crimes like brutal maltreatment falling short of killing, deliberate perversion of justice by the courts and administering harmful performance-enhancing drugs to sportspeople. The hard-working prosecutors had reached a decision in 16,494 of these 16,503 cases (so almost all of them). In most cases their decision was that no prosecution should be brought because the prospects of success were not good enough. In 261 cases the prosecutors had decided to prosecute. Of these 261 prosecutions:

- 159 were of judges and lawyers who had worked in the GDR's judicial system. In all, there were 226 accused. The most important prosecutions were those of former judges of the GDR's Supreme Court (Oberstes Gericht) and former prosecutors. These people were prosecuted for perversion of justice. 
Only 53 of the accused were actually convicted of crimes and most of these did not have to go to jail.

- 72 were of former officers of the Stasi (there were 101 accused in these proceedings). Only 33 were convicted of crimes; only one of these went to jail.

- 23 prosecutions concerned the unlawful administration of drugs to athletes and were of the officials, doctors and athletic coaches involved. There were 49 accused in all. 36 were convicted, but no one went to jail. 24 terms of imprisonment were handed down but they were all suspended.

- The percentage of those investigated who were put on trial was very small (approximately 1.58\%). This percentage is much smaller than that which prevails in other criminal investigations (between 10 and 15\%). The prosecutors consider this to be proof positive that the accused were not victims of "victors' justice". Even the percentage of criminal investigations (relative to the population of East Germany) carried out was much smaller than the percentage of ordinary criminal investigations in any year in West Germany. ${ }^{50}$

In the ten years before 3 October 2000, the Berlin state prosecutor also carried out 6,425 investigations into the more serious category of acts of violence against wouldbe escapees. Only 112 of these investigations led to prosecutions (against 246 accused). In the ensuing trials 123 accused were convicted of criminal offences; these accused included 7 former members of the GDR's political leadership, 36 former members of its military leadership and 80 former soldiers of the GDR's border guard. Only 25 people had to serve terms of imprisonment. However, among these were 6 
former members of the GDR's political leadership and 17 former members of its military leadership.

The Berlin state prosecutor transferred a further 158 cases to other prosecution authorities so that they could consider whether to bring prosecutions. This led to at least 127 further prosecutions in other parts of Germany for acts of violence against people attempting to escape from the GDR.

Like their colleague in Berlin, the other main prosecution authorities brought very few prosecutions. Across the six main prosecutors (the five new federal states and Berlin), only about $1 \%$ of investigations culminated in a prosecution. Most were of state and Stasi officials for some serious illegality or other. There were fewer (though still significant numbers) in the graver categories of perversion of justice and acts of violence on the inner-German border. Only a small percentage (about 5\%) of those convicted of crime have actually had to serve a term of imprisonment. About a third of the accused were acquitted. No one was convicted of eavesdropping unlawfully on telephone calls or of illegal interception of post. ${ }^{51}$

The sentences the courts have handed down have been very lenient, reflecting the difficulties involved in prosecuting officials of this particular dictatorship. Some of the accused were so old that long prison terms could have represented cruel punishment. By contrast, others were so young when they committed their crimes, and had been such lowly servants of a regime which had all their lives deliberately tried to indoctrinate them and arouse anti-Western feelings in them, that their responsibility for their crimes could reasonably be said to have been diminished. The 
more important people received the longer jail terms. Politburo members served terms of between 3 and 6-and-a-half years. ${ }^{52}$

The prosecutions of some Communist leaders were abandoned owing to the poor state of their health. Erich Mielke and the GDR's former Prime Minister, Willi Stoph, for example, were not prosecuted for their role in maintaining the GDR's vicious border regime. They were treated far more indulgently than Nazi war criminals, who even in recent years have been prosecuted despite their great age and the length of time that has passed since they committed their crimes. For instance, Dr Friedrich Engel, then aged 93, was prosecuted in 2002 in Hamburg for the murder of 59 Italian prisoners in Italy in May 1944, 58 years previously. He was convicted of murder and sentenced to 7 years' imprisonment. The prosecutors consider this to be further evidence that they did not engage in "victors' justice". 53

The post-unification German government also ensured that the convictions of those who were unjustly convicted of political crimes by GDR courts were quashed and the victims compensated. $^{54}$

The alternative to this huge effort to investigate each individual instance of politically-motivated crime committed over a period of 45 years and assess its legality under the law of a since-dissolved state would have been to amend the Basic Law and insert in the Unification Treaty a provision for the retroactive application of a special body of legal principles specifically applying to crimes committed in the service of the East German Communist regime. Amendment of the Basic Law would have 
required the support of a two-thirds majority in the Bundestag. This might well have been obtained, but the effort was not made to obtain it. ${ }^{55}$

The obstacles to successful prosecutions have been even greater in the Romanian case and have prevented all but a very few trials of wrongdoers for crimes committed during the Communists' time in power. These obstacles have been a lack of political will owing to the collaboration with the Communist regime of politicians, judges, prosecutors and a large section of the public, legal difficulties arising from a presidential pardon decree of January 1988, the statute of limitations and the principle of non-retroactivity, a lack of evidence owing to its destruction by the Communists, and the age and infirmity of some of the potential accused (particularly those who participated in the vicious mass repression which took place between 1949 and 1964).

The courts have not been independent of the executive and have not been willing to hear cases against former Communists with political protection. Prosecutors have invoked the principle of non-retroactivity and refused to prosecute. The post-1989 governments could have overcome the barrier presented by the statute of limitations by treating crimes committed by Communists as crimes against humanity and making these ones not subject to the statute. The latter step would have been consistent with international law: that crimes against humanity should not be subject to any limitation period is an accepted principle of international law pursuant to a convention of 1968 which Romania signed. ${ }^{56}$ However, the post-1989 governments have not taken either step - a striking failure, at least on the part of the reformist, pro-democratic parties. The presence in them of ex-Communists, including former Securitate officers and informers, was probably one of the reasons for this - lustration would have increased 
the political will in Romania to try those who had committed crimes against humanity. The Romanian Ministry of Justice refuses to prosecute on the basis of the 1968 convention, claiming that this would infringe the principle of non-retroactivity. This is the flat opposite of the reasoning of the German courts, which have held that the principle of non-retroactivity does not apply because even the Communist regimes accepted that they were subject to international law.

Quite a large number of trials have taken place in Romania (112 before the military courts), but they have overwhelmingly related to the killing of unarmed demonstrators during the anti-Communist uprising of December 1989 and the use by the neoCommunist regime, in June 1990, of miners bussed to Bucharest to harass the opposition to it. There has been almost no effort to bring to justice those responsible for vicious Communist repression in the years 1945-89, even though the number of their victims is far greater than the number of those who died in the uprising of 1989. This conforms to a pattern throughout Central and Eastern Europe: with the exception of Germany, no former Communist country has tried more than 36 wrongdoers for crimes committed during the period of Communist rule. ${ }^{57}$

\section{History-writing and journalism}

The Stasi's files are expressly, by law, to be made available to historians, journalists and other researchers to ensure that the long-secret role of the Stasi in maintaining the Communist regime in power is revealed to its victims and the whole world. This task is becoming an increasingly important one for the BStU since, firstly, its responsibility for vetting will end in the future and, secondly, most of those on whom 
the Stasi kept a file and who want to read it have already done so, making this also a declining area of activity for the agency.

To ensure that historical research was undertaken, the Law on the Stasi Records provided for the establishment of a special team of researchers, employed by the BStU, to publish histories of the Stasi and its operations. Despite a reform undertaken in 2006, the researchers of the BStU's Research and Education Department (Abteilung Bildung und Forschung) still have privileged access to the Stasi's records since they may read them in the original, without any redactions, whereas most other researchers may only read either original files which contain no personal information (or other information exempt from release) or copies from which this information has been redacted. They must also wait for a long time for access to the records for which they have applied and have to rely on a case officer being competent to make suitable records available to them. (The BStU's researchers are under the same legal restrictions as other readers as regards what they publish.)

The BStU researchers' works dominate the academic literature on the Stasi - for better and for worse. Research on the Stasi has advanced further than research on any other Communist security service; this is to some extent down to the BStU's own researchers, who started their work earlier than researchers in the other ex-Communist states. Moreover, as has been mentioned above, fewer records were destroyed in East Germany than elsewhere. ${ }^{58}$ They have done much to shed light on the repression carried out by the Stasi. However, the researchers' research agenda has not been comprehensive. To give just two examples, more than twenty years after the Stasi was dissolved, there is very little work on its large-scale counter-intelligence operations, 
and little attempt has been made to compare the Stasi's activities with those of the other security services of the Soviet Bloc. There has also been little engagement in the BStU's publications with the academic literature on intelligence in other languages (particularly English). The BStU's publications vary greatly in quality, the best having been written by a few prolific individuals. There is much to be said for facilitating further research on the Stasi by $\mathrm{PhD}$ students and scholars who have been through the university system; such people would broaden the range of perspectives on the Stasi and be better able to integrate scholarship on the Stasi into the literature on intelligence available in other languages.

Romania has, again, been less fortunate. The Communists remained in power longer and the state security service remained longer in possession of its records. Many have been destroyed. How many no one will ever know. The SRI's archivist has suggested that 130,000 files were destroyed during the uprising of 1989 , but this estimate is only one of many (the Romanian Information Service's figure was 27,000, which may be an indication of how unreliable its figures are). The figure of 130,000 also does not include the files which were been destroyed in the 45 years before 1989. Estimates relating to the latter category of destroyed files run into the hundreds of thousands. It is not known where to find many of those that have not been destroyed. Consequently, the size of the available archive is unknown. More than 1.9 million files are known to exist.

Starting later, when fewer records were available and when it was not known what records were available, has meant that serious historical writing about the Securitate has barely begun. There is uncertainty about key aspects of the service's history. The 
records destroyed at the order of the Communist Party in the late 1960s $(273,805$ files on "collaborators", according to the Romanian Information Service) concerned party members who supplied information to the Securitate; those who destroyed them were keen to ensure that the party's close involvement in the security service's surveillance and repression remained obscure. ${ }^{59}$ Such destruction will create significant gaps in the histories of the service that can be written. Another example is the size of its informer network. The Securitate made a distinction between "collaborators" (who were Communist Party members who provided it with information) and "informers" who were non-party members who reported to it. Official figures for the size of its human informant network seem to have been obtained from the SRI in 1993. They were that 507,003 "informers" reported to it during the course of the regime and an unknown further number of "collaborators". The figure of 507,003 seems to be based on the number of informer files in existence in 1993 and therefore does not take account of file destruction (at least 78,000 files are believed to have been destroyed in the years 1989-93 alone). ${ }^{60}$ In 1989 the Securitate had an informer network of 144,289 people and a full-time staff of 15,087 officers. This force monitored a population of 21.5 million people. ${ }^{61}$ These figures are far from being accepted. A former Securitate officer, Liviu Turcu, has maintained that there were one million informants. The Romanian Information Service long claimed that about 100,000 informers reported to the Securitate. This figure is believed to be far too small. ${ }^{62}$ There are no reliable figures for the size of the informant network after 1989.

These uncertainties do not exist in the German case. The size of the Stasi, including its network, is known: some 174,000 informers in 1989 , reporting to a full-time staff of 102,000 officers. ${ }^{63}$ Lavinia Stan, the leading authority on Romania's efforts to 
come to terms with its Communist past, claims that Romania had a larger informer network, relative to the population's size, than East Germany. This is unlikely to have been the case. ${ }^{64}$

\section{Conclusion}

The force driving the opening of the state security archives has been political: the determination to de-communize. Since much Communist repression took place secretly, the opening of state security records has been essential to de-communization.

The main benefit is also political. This is seen in all four processes the state security archives have served. Germany has derived the biggest benefit because it has had the political and judicial will to take effective measures of de-communization. The other former Communist states have been less successful in banishing the ghost of Communism. The one striking success throughout Central and Eastern Europe is that the opening of the files has led to no acts of vengeance against state security officers or informers. ${ }^{65}$

Lustration was meant to encourage social trust in democratic institutions. Germany was very fortunate in being able to move forward quickly with it, before large numbers of Stasi records had been destroyed, removed or forged. Consequently, vetting and lustration have been successful and have enjoyed public confidence. Although how to interpret the records has been the subject of much dispute (in Germany as everywhere else), few objections have been raised to their reliability. ${ }^{66}$ 
Those who pressed for de-communization in Romania were in a much weaker position. Shedding light on the past was above all the cause of former political prisoners (a dwindling number of people). However, the political position of the Communists was too strong, authoritarian political traditions were too entrenched, the courts too craven and compromised, and the organizations of civil society too weak for them to achieve anything but slow and partial progress. The failure to expose police informers in public office may undermine confidence in Romania's democratic institutions for a long time to come. ${ }^{67}$ It has certainly diminished the political will in Romania for prosecution of people for serious crimes and grave infringements of human rights. In its turn, the failure to prosecute these people may also long weaken public confidence in democratic institutions and the rule of law. Germany's trials have enjoyed public confidence and have, for most, further made the case for the democratic Rechtsstaat (state based on law).

While the BStU's findings as to who the Stasi's informers were have attracted very little criticism, the same is not true of those of Romania's CNSAS. One grave mistake made in Romania was to make the National Council's leadership political nominees. This made it partisan and undermined public confidence in its work. The courts are also partisan and it is unlikely that lustration will make progress now that they are in the driving seat. By contrast, Germany's Federal Commissioner, who is elected by the Bundestag, is not politically partisan. His/her office is independent of the political parties; its work has not served their interests. ${ }^{68}$

Lustration has also had unintended effects. Severe lustration in the public service in the Czech Republic encouraged former Communists to go into business, where many, 
exploiting their money and contacts, have thrived. Among them are people suspected of wielding more influence as businessmen than they would have had if they had remained in the public service. ${ }^{69}$

The Law on the Stasi Records has significantly improved understanding of the GDR's Communist regime, both on the part of its victims and on that of the reading public as a whole. Let us consider the victims first. The very act of making their files available to the Stasi's targets is an acknowledgement that they may have suffered - indeed, probably or certainly did suffer - injustice. Many such people have demanded to know the truth about their surveillance and persecution; in their cases, the opening of the Stasi's archive has satisfied this demand. Reading their files gives some deep satisfaction; it underlines that they have outlasted the regime that wronged them and can take issue with the contents of the file. Betrayal and deceit have ended. ${ }^{70}$ By contrast, reading their files has caused others great distress. In every case, the law has helped them to understand how the regime proceeded against them. Since so many more Germans have applied to see their files (2.75 million, as against 34,249), it is clear that Germans are more satisfied with their rights of access than the Romanians (or Hungarians) are with theirs.

However, a very clear benefit of the opening of files to individuals has gone to the broader society of Germany rather than the community of victims. ${ }^{71}$ It has made the political point to all that under Communist rule East German society was based on betrayal; for all the economic hardship and political marginalization of which East Germans have complained since 1990, this has continued to discredit the Communist regime and strengthened the legitimacy in the eyes of most Germans, East and West, 
of the Federal Republic's democratic institutions. The StUG has provided an important corrective to that marginalization and hardship, binding East Germans to the Federal Republic and its political system. The StUG has undoubtedly helped to create a more open society and political system than existed in East Germany before and to enhance public trust in Germany's democratic institutions, political parties and public service. That said, it has done so at the price of creating a disaffected class: that of the Stasi's ex-officers and informers, many of whom have been marginalized in society and have registered their protest by turning to the successor party to the Socialist Unity Party (long called the PDS but now known as "Die Linke"). ${ }^{72}$

Public understanding of the GDR's Communist regime has also been considerably improved. Of course, professional historians and political scientists are more interested in this than the general public; their work has profited greatly from the StUG. For example, the law has enabled the entire informer network of the Stasi, both within the GDR and in the Federal Republic, to be uncovered - an achievement unprecedented in history. ${ }^{73}$ This has transformed historians' understanding of how a Communist regime controlled its people. The Stasi's informer network has been revealed to be smaller than many feared when the GDR collapsed, dealing a blow to the myth of the security service's omnipotence. (This is also a victory for the Federal Republic's democratic system, of course.)

Just as enough Securitate records have been destroyed to undermine public confidence in the vetting and lustration process, so the destruction may have been great enough to create significant gaps in the histories of Communism in Romania which will surely emerge. However, the size of the archive is such that it will surely 
remain possible to write good, sound histories of the Securitate. The BStU has shown much ingenuity in overcoming gaps caused by destruction of some of the Stasi's archives and the Romanians may have similar success in filling in gaps in their archive. Thorough exploitation of the Securitate's archive will transform the historiography of Romanian Communism. The destruction of the archive, which some have called for, would have been a terrible loss, both to historians and to Romanians' hopes of establishing a successful democracy.

${ }^{1}$ Laws were passed in the states of the former Soviet Bloc between 1991 (Germany and Czechoslovakia) and 1999 (Romania). The states of ex-Yugoslavia still remained unaffected by the trend. However, Slovenia passed such a law in 2004. In 2006 Albania agreed to open some state security files.

${ }^{2}$ The same did not happen in the former republics of the Soviet Union because large numbers of their state security records were moved to Moscow before the USSR was dissolved.

${ }^{3}$ Foreword to Lavinia Stan (ed.), Transitional Justice in Eastern Europe and the Former Soviet Union: Reckoning with the Communist Past (London: Routledge, 2009), p. xiii.

${ }^{4}$ Krzysztof Persak \& Lukasz Kaminski (eds.), A Handbook of the Communist Security Apparatus in East-Central Europe, 1944-1989 (Warsaw: Institute of National Remembrance, 2005), p. 9.

${ }^{5}$ Paul Maddrell, "The Revolution Made Law: The Work since 2001 of the Federal Commissioner for the Records of the State Security Service of the Former German Democratic Republic", Cold War History, vol. 4, no. 3 (2004), pp. 153-62 at pp. 1534. 
${ }^{6}$ A. James MacAdams, Judging the Past in Unified Germany (Cambridge: Cambridge University Press, 2001), p. 2; John Miller, "Settling Accounts with a Secret Police: The German Law on the Stasi Records", Europe-Asia Studies, vol. 50, no. 2 (1998), pp. $305-33$ at p. 307.

${ }^{7}$ This anomaly is particularly severe in the Czechoslovakian case because the security service, the StB, stopped registering informers as such when they joined the Party. ${ }^{8}$ The tags used to describe the two policy extremes are "prosecute and punish" and "forgive and forget". Germany and the Czech Republic represent the first tendency; Slovakia and Hungary the latter one. Romania and Poland are also in the latter camp, though have gone further than the other two in particular respects. ${ }^{9}$ See:

http://www.bstu.bund.de/DE/BundesbeauftragterUndBehoerde/Rechtsgrundlagen/StU G/StUG_novelle_2011/stug_novelle_node.html

${ }^{10}$ Miller, "Settling Accounts with a Secret Police: The German Law on the Stasi Records”, p. 315; Gary Bruce, "East Germany”, in Stan (ed.), Transitional Justice in Eastern Europe and the Former Soviet Union, pp. 27-9.

${ }^{11}$ Nadya Nedelsky, "Czechoslovakia and the Czech and Slovak Republics", in Stan (ed.), Transitional Justice in Eastern Europe and the Former Soviet Union, p. 45. Between October 1991, when the law came into force, and November 2005, no fewer than 451,000 lustration certificates (containing findings) were issued. Only $2.03 \%$ of them found that the person concerned had collaborated with the security service, the StB (Nedelsky, p. 49).

${ }^{12}$ Lavinia Stan, "Poland", in Stan (ed.), Transitional Justice in Eastern Europe and the Former Soviet Union, pp. 76-86. 
${ }^{13}$ Lavinia Stan, "Hungary”, in Stan (ed.), Transitional Justice in Eastern Europe and the Former Soviet Union, pp. 110-11.

${ }^{14}$ Lavinia Stan, "Romania”, in Stan (ed.), Transitional Justice in Eastern Europe and the Former Soviet Union, pp. 137-8.

${ }^{15}$ Nedelsky, "Czechoslovakia and the Czech and Slovak Republics", in Stan (ed.), Transitional Justice in Eastern Europe and the Former Soviet Union, p. 38.

${ }^{16}$ Its full name is the Law on Access to Files and Exposure of the Securitate as a Political Police: see Lavinia Stan, "Spies, Files and Lies: Explaining the Failure of Access to Securitate Files", Communist and Post-Communist Studies, vol. 37, no. 3 (2004), pp. $341-59$ at p. 342.

${ }^{17}$ The SRI was established by a Decree No. 181 of 26 March 1990.

${ }^{18}$ Stan, "Spies, Files and Lies: Explaining the Failure of Access to Securitate Files", pp. 351-2.

${ }^{19}$ Stan (ed.), Transitional Justice in Eastern Europe and the Former Soviet Union, p. 9.

${ }^{20}$ Stan, "Access to Securitate Files: The Trials and Tribulations of a Romanian Law", East European Politics and Societies, vol. 16, no. 1 (2002), pp. 145-81 at pp. 153-4. ${ }^{21}$ Stan, "Spies, Files and Lies: Explaining the Failure of Access to Securitate Files", pp. 344-5.

${ }^{22}$ Stan, "Romania", in Stan (ed.), Transitional Justice in Eastern Europe and the Former Soviet Union, pp. 138-9.

${ }^{23}$ Lavinia Stan, Transitional Justice in Post-Communist Romania: The Politics of Memory (Cambridge: Cambridge University Press, 2012), pp. 98-9. Some 3,000 more informers have been identified in the course of making victims' files available to them. 
${ }^{24}$ Stan, Transitional Justice in Post-Communist Romania, pp. 84-5.

${ }^{25}$ Stan, "Access to Securitate Files: The Trials and Tribulations of a Romanian Law", pp. 168-71, 180-1.

${ }^{26}$ Lavinia Stan, "Moral Cleansing Romanian Style", Problems of Post-Communism, vol. 49, no. 4 (2002), pp. 52-62 at p. 54.

${ }^{27}$ Stan, Transitional Justice in Post-Communist Romania, pp. 105-10.

${ }^{28}$ Stan, "Romania", in Stan (ed.), Transitional Justice in Eastern Europe and the Former Soviet Union, pp. 139-40; Stan, "Spies, Files and Lies: Explaining the Failure of Access to Securitate Files”, p. 353.

${ }^{29}$ Stan, "Access to Securitate Files: The Trials and Tribulations of a Romanian Law", p. 155.

${ }^{30}$ Stan, "Access to Securitate Files: The Trials and Tribulations of a Romanian Law", pp. 172-6.

${ }^{31}$ Stan, Transitional Justice in Post-Communist Romania, pp. 95-8.

${ }^{32}$ Cynthia Horne, "Late Lustration Programmes in Romania and Poland: Supporting or Undermining Democratic Transitions?”, Democratization, vol. 16, no. 2 (2009), pp. 344-76.

${ }^{33}$ Zehnter Tätigkeitsbericht der Bundesbeauftragten für die Unterlagen des Staatssicherheitsdienstes der ehemaligen Deutschen Demokratischen Republik (Berlin: BStU, 2011), p. 50.

${ }^{34}$ Stan, "Access to Securitate Files: The Trials and Tribulations of a Romanian Law", pp. 162-3.

${ }^{35}$ Stan, Transitional Justice in Post-Communist Romania, pp. 73-4.

${ }^{36}$ Nedelsky, "Czechoslovakia and the Czech and Slovak Republics”, in Stan (ed.), Transitional Justice in Eastern Europe and the Former Soviet Union, pp. 51-3. 
${ }^{37}$ Stan, "Hungary", in Stan (ed.), Transitional Justice in Eastern Europe and the Former Soviet Union, pp. 116-18.

${ }^{38}$ Stan, Transitional Justice in Post-Communist Romania, p. 59.

${ }^{39}$ MacAdams, Judging the Past in Unified Germany, pp. 25, 29-30.

${ }^{40}$ Bernhard Jahntz, "Die juristische Aufarbeitung der SED-Herrschaft - eine vorläufige Bilanz", in Siegfried Suckut \& Jürgen Weber (Hrsg.), Stasi-Akten zwischen Politik und Zeitgeschichte: eine Zwischenbilanz (München: Olzog, 2003), p. 324.

${ }^{41}$ Jahntz, "Die juristische Aufarbeitung der SED-Herrschaft - eine vorläufige Bilanz", p. 312 .

${ }^{42}$ Roman Grafe, "Generalstaatsanwalt Christoph Schaefgen: 'Wenig aufbauend ist die zahlenmäßige Bilanz unserer Arbeit'. Die Strafverfolgung von SED-Unrecht 19901998", Deutschland Archiv, vol. 32, no. 1 (1999), pp. 6-8 at p. 7.

${ }^{43}$ Jahntz, "Die juristische Aufarbeitung der SED-Herrschaft - eine vorläufige Bilanz", p. 311 .

${ }^{44}$ Gary Bruce, "East Germany”, in Stan (ed.), Transitional Justice in Eastern Europe and the Former Soviet Union, pp. 25-7.

${ }^{45}$ A further 150 people were injured by exploding mines when trying to escape.

${ }^{46}$ For example, they relied on para. 27 of the GDR's 1982 Border Law (Grenzgesetz), which had specifically authorized firing on escapees.

${ }^{47}$ MacAdams, Judging the Past in Unified Germany, pp. 30-4.

${ }^{48}$ Jahntz, "Die juristische Aufarbeitung der SED-Herrschaft - eine vorläufige Bilanz", pp. 319-23.

${ }^{49}$ Jahntz, "Die juristische Aufarbeitung der SED-Herrschaft - eine vorläufige Bilanz", pp. $329-32$. 
${ }^{50}$ Jahntz, "Die juristische Aufarbeitung der SED-Herrschaft - eine vorläufige Bilanz", pp. 325-6.

${ }^{51}$ Grafe, "Generalstaatsanwalt Christoph Schaefgen: 'Wenig aufbauend ist die zahlenmäßige Bilanz unserer Arbeit'. Die Strafverfolgung von SED-Unrecht 19901998”, pp. 7-8.

${ }^{52}$ Jahntz, "Die juristische Aufarbeitung der SED-Herrschaft - eine vorläufige Bilanz”, pp. 326-8; MacAdams, Judging the Past in Unified Germany, pp. 35-41.

${ }^{53}$ Jahntz, "Die juristische Aufarbeitung der SED-Herrschaft - eine vorläufige Bilanz”, p. 333.

${ }^{54}$ MacAdams, Judging the Past in Unified Germany, p. 3.

55 Jahntz, "Die juristische Aufarbeitung der SED-Herrschaft - eine vorläufige Bilanz”, pp. 313-14.

${ }^{56}$ This is the Convention on the Non-applicability of Statutory Limitations to War Crimes and Crimes against Humanity of 26 November 1968 - see:

http://www2.ohchr.org/english/law/warcrimes.htm

${ }^{57}$ Stan, Transitional Justice in Post-Communist Romania, pp. 30-41; Stan, "Romania", in Stan (ed.), Transitional Justice in Eastern Europe and the Former Soviet Union, pp. 140-8.

${ }^{58}$ Persak \& Kaminski, A Handbook of the Communist Security Apparatus in EastCentral Europe, 1944-1989, p. 9.

${ }^{59}$ Stan, "Moral Cleansing Romanian Style", p. 58. The destruction operation was called "Jarul" ("ashes") and took place in the late 1960s and early 1970s.

${ }^{60}$ Stan, "Moral Cleansing Romanian Style", p. 56.

${ }^{61}$ Stan, Transitional Justice in Post-Communist Romania, pp. 9, 69-70; Stan, "Moral Cleansing Romanian Style", p. 55. 
${ }^{62}$ Stan, "Access to Securitate Files: The Trials and Tribulations of a Romanian Law", pp. 159-62.

${ }^{63}$ Helmut Müller-Enbergs (ed.), Inoffizielle Mitarbeiter des Ministeriums für Staatssicherheit: Richtlinien und Durchführungsbestimmungen (Berlin: Links Verlag, 1996, $2^{\text {nd }}$ edition), p. 7.

${ }^{64}$ Stan, who gives these figures, is inconsistent in her use of them (she gives the figure of 507,003 "informers" as both the number of informers in 1989 and the number throughout the period 1945-89). She seems to mean the latter. On the basis of them she claims that the percentage of the Romanian population who collaborated, in one way or another, with the Securitate was at least $3.4 \%$ and that the percentage of the East German population which supplied information to the Stasi was only $2.5 \%$. However, these percentages are inconsistent with the figures she cites because over the course of its existence (1950-89) the Stasi ran an informer network of between one and two million people (see David Childs and Richard Popplewell, The Stasi: The East German Intelligence and Security Service (London: Macmillan, 1996), p. 86). Its informer network probably represented a larger percentage of the East German population than the Securitate's did of the Romanian population. The Stasi's full-time staff in 1989 was also larger relative to the size of the population.

${ }^{65}$ E.g. Stan, Transitional Justice in Post-Communist Romania, p. 83.

${ }^{66}$ MacAdams, Judging the Past in Unified Germany, p. 19.

${ }^{67}$ See Stan, Transitional Justice in Post-Communist Romania, pp. 28-30.

${ }^{68}$ Miller, "Settling Accounts with a Secret Police: The German Law on the Stasi Records", pp. 309-10.

${ }^{69}$ Nedelsky, "Czechoslovakia and the Czech and Slovak Republics”, in Stan (ed.), Transitional Justice in Eastern Europe and the Former Soviet Union, pp. 62-4. 
${ }^{70}$ Stan, Transitional Justice in Post-Communist Romania, p. 75.

${ }^{71}$ This is consistent with other examples of truth recovery as well: see Marie Breen Smyth, Truth Recovery and Justice after Conflict: Managing Violent Pasts (Abingdon: Routledge, 2007), pp. 174-7.

${ }^{72}$ Miller, "Settling Accounts with a Secret Police: The German Law on the Stasi Records”, pp. 317-23.

${ }^{73}$ Helmut Müller-Enbergs, “Kleine Geschichte zum Findhilfsmittel namens Rosenholz",, Deutschland Archiv (2003), no. 5, pp. 751-61 at p. 751. 